\title{
Efecto de la tenacidad del asfalto en la resistencia a fatiga de las mezclas asfálticas
}

\section{Asphalt toughness effect on bituminous mixture fatigue behavior}

\author{
Alfredo H. Noguera*1, Rodrigo Miró** \\ * Universidad Nacional Autónomo de México UNAM. MÉXICO \\ ** Universidad Politécnica de Cataluña. ESPAÑA
}

Fecha de recepción: $27 / 10 / 2010$ Fecha de aceptación: 20/ 05/ 2011

Resumen

PAG. 224 - 239

\begin{abstract}
Uno de los parámetros más importantes para definir el comportamiento de la mezcla en servicio es la tenacidad que el asfalto proporciona al aglomerar los agregados, es decir, la energía que se disipa al fracturar la mezcla, entre mayor sea dicha energía mejor será su calidad. Y por lo tanto, deberá existir una relación si dicha cantidad de energía se disipa en un ciclo de carga (tracción) o con muchos ciclos durante el tiempo (fatiga). El objetivo de éste trabajo es establecer una relación entre la tenacidad que ofrecen distintos asfaltos y el comportamiento a fatiga de sus correspondientes mezclas asfálticas, para lo cual, se ha obtenido la tenacidad mediante un ensayo de tracción directa y se ha comparado con los valores de las leyes de fatiga y energía disipada obtenidas del ensayo de flexo-tracción dinámica.
\end{abstract}

Palabras Clave: Asfalto, agregados, mezcla asfáltica, tenacidad, fatiga

Abstract

One of the most important parameters to define bituminous mixture behavior in service is the toughness that the bitumen provides when binding the aggregate particles; that is; the dissipated energy during the materials fracture process. The greater the dissipated energy in fracture, the better the bituminous mixture quality is. Hence, a relationship will have to exist if the toughness is removed during one load cycle (direct tension) or during many cycles along time (fatigue). The purpose of this study is to determinate relationships between the toughness of different bitumens and the fatigue behavior of their corresponding bituminous mixtures, for which, the toughness has been obtained by means of direct tension test and has been compared with the value of the fatigue law and dissipated energy obtained by fatigue bending test. Results showed that, this study expect to give important means for further research to predict fatigue life from a static test.

Keywords: Bitumen, aggregates, bituminous mixture, tenacity, fatigue

\section{Introducción}

La mezcla asfáltica es un material complejo multifase constituido por asfalto, agregado mineral graduado y aire, por lo que pueden obtenerse una gran variedad de tipos de mezclas asfálticas combinando estos componentes. Una de las características más importantes a analizar en el comportamiento de la mezcla es la variabilidad en la resistencia entre el esqueleto mineral y el asfalto (Wagoner et al., 2007; A. N. Kvasnak et al., 2007; Kowalski et al., 2008; Kringos et al., 2008).

Esta resistencia, también llamada tenacidad de la mezcla, es posible analizarla desde el punto de vista de energía disipada, es decir, una mezcla con una mayor capacidad para disipar energía será capaz de resistir las cargas de tráfico sin disgregarse o fracturarse. La mecánica de fractura ha aceptado este tipo de análisis de fallo en distintos materiales, incluyendo las mezclas asfálticas.

\section{Introduction}

Bituminous mixture is a complex multiphase material constitued by asphalt, mineral aggregate graduate and air, so a great variety of asphalt mixtures can be obtained from the mixture of these components. One of the most important characteristics to analyze in the mixture behavior is variability among the resistance of mineral skeleton and asphalt (Wagoner et al., 2007; A. N. Kvasnak et al., 2007; Kowalski et al., 2008; Kringos et al., 2008).

This resistance, also called the toughness of the mixture, can be analyzed from the point of view of dissipated energy, ie, a mixture with greater capacity to dissipate energy will be able to withstand traffic loads without disintegrating or breaking. The fracture mechanics has accepted this type of failure analysis in various materials, including asphalt.

\footnotetext{
1 Autor de correspondencia / Corresponding author:

E-mail: JHernandezN@iingen.unam.mx
} 
Dicha energía depende del trabajo termodinámico de la tenacidad, mecánica de fractura y reología (E. H. Fini et al., 2007; Arago et al., 2011).

De acuerdo con el moderno punto de vista sobre este tema, durante la acción de la fuerza de tensión se desarrolla un trabajo que se almacena en forma de energía de deformación. Cuando esta energía alcanza la magnitud de la densidad de energía de fractura superficial del material $G_{f}$, ocurre la fractura y la pieza se separa en dos partes liberando la energía en forma de fractura, tal que cada una de las partes relaja inmediatamente sus tensiones. La energía de fractura $G_{f}$ ha probado ser un buen parámetro de diseño que puede ser usado en la mecánica de fractura para analizar la propagación de la grieta de un pavimento (Shen et al., 2007; Kim et al., 2009; E. Denneman, 2010).

Asociado a la tenacidad existe otro fenómeno de disipación de energía de una mezcla asfáltica y es la fatiga del sistema agregado-asfalto, donde el compuesto va perdiendo gradualmente su energía disponible debido a cargas de corta duración cada vez que pasa un vehículo (Adhikari et al., 2009). En la especificación actual de SUPERPAVE, se considera que la fatiga no se presenta si el asfalto cumple con un valor reológico mínimo de $\mathrm{G}^{*}$ sen$\delta$. Este valor representa una disminución del módulo complejo y está relacionado con el total de la energía disipada por ciclo de carga (D’Angelo et al., 2007). Sin embargo, diversos estudios han demostrado que no existe una correlación entre los valores reológicos y el comportamiento de la mezcla en servicio.

Con la finalidad contribuir a un mejor entendimiento de los procesos internos del sistema agregado-asfalto y su correlación con la fatiga del mismo, se ha desarrollado este trabajo, empleando el ensayo Barcelona Tracción Directa (BTD) para determinar la tenacidad de diferentes asfaltos (Pérez Jiménez et al., 1997) y el ensayo de flexotracción de 3 puntos (NLT350/90), para determinar la fatiga de una mezcla fabricada a partir de estas asflatos.

\subsection{Significancia de la investigación}

Aunque numerosos trabajos han propuesto varios métodos o ensayos para determinar la fatiga en mezclas asfálticas, como los ensayos de compresión cíclica o los ensayos de flexotracción dinámica, aún actualmente estos ensayos son complejos, requieren mucho trabajo para la fabricación de probetas y el tiempo de ensayo es largo. Por tanto, lo ideal sería poder establecer una relación con la fatiga a partir de ensayos en los asfaltos o másticos.
This energy depends on the thermodynamic work of toughness, fracture mechanics and rheology (E. H. Fini et al., 2007; Arago et al., 2011).

According to modern views regarding this subject, during the action of tension force a work develops and it is stored as strain energy. When this energy reaches the magnitude of the density of fracture energy $G_{f}$ material surface, the fracture occurs and the piece splits in two parts, releasing energy in the form of fracture, in such a way that each part immediately relaxes its tensions. The fracture energy $G_{f}$ has proven to be a good design parameter that can be used in fracture mechanics to analyze the crack propagation of a pavement (Shen et. al., 2007; Kim et al., 2009; E. Denneman, 2010).

Associated with toughness there is another phenomenon of energy dissipation of bituminous mixture and it is fatigue of aggregate-asphalt system, wherein the compound gradually loses its available energy due to short duration loads every time that a vehicle passes (Adhikari et al., 2009). In the current SUPERPAVE specification, it is considered that fatigue does not occur if asphalt meets a minimum rheological value of $G^{*}$ sen $\delta$. This value represents a decrease of complex modulus and is related to total dissipated energy per load cycle (D’Angelo et al., 2007). However, several studies have shown that there is no correlation between the rheological values and mixing behavior in service.

In order to contribute to a better understanding of the internal processes of asphalt-aggregate system and its correlation with its fatigue, this study has been developed using the essay Barcelona Direct Traction (BDT) to determine toughness of different asphalt (Pérez Jiménez et al., 1997) and testing of 3-point flexural (NLT$350 / 90)$, to determine the fatigue of a mixture made from these asphalts.

\subsection{Research significance}

Even if numerous studies have proposed various methods or tests to determine fatigue in asphalt mixtures, such as cyclic compression tests and dynamic flexural tests, even today these tests are complex and they require a lot of work for test tubes production, and also trial time is long. Therefore, the ideal would be to establish a relationship with fatigue from tests on asphalt or mastic. 
En este trabajo se pretende establecer una relación entre la tenacidad que ofrecen distintos asfaltos y el comportamiento a fatiga de sus correspondientes mezclas asfálticas. Conociendo esta relación, podría tenerse una idea del comportamiento a fatiga de la mezcla a partir de los ensayos de tenacidad del asfalto, que son monotónicos y por lo tanto, más fáciles y rápidos de hacer, y con ello, poder tener en cuenta esta propiedad en la etapa de diseño.

\section{Materiales}

Los asfaltos utilizados en los ensayos experimentales son, dos asfaltos de penetración, B-60/70 y B-13/22; dos asfaltos modificados con polímeros, BM3с у BM-3b, recogidos en el pliego de prescripciones técnicas generales (PG-3). Además, se ha empleado un asfalto modificado con polvo de neumático BM-PN. Las propiedades de cada uno de los asfaltos son recogidas en la siguiente Tabla:
This paper aims to establish a relationship between the toughness that offer different asphalts and fatigue behavior of the corresponding bituminous mixture. Knowing this relationship, one could have an idea of the fatigue behavior of the mixture from the toughness tests of asphalt, which are monotonic and therefore easier and faster to make, and be empowered to take account of this property in the design stage.

\section{Materials}

Asphalt used in experimental trials are: two penetration asphalts, $B-60 / 70$ and $B-13 / 22$; two asphalts modified with polymers, BM-3c and BM-3b, collected in the General Technical Specifications (PG-3). It has also been used a modified asphalt with crumb rubber BMPN. Asphalts properties are the following:

Tabla 1. Caracterización de los asfaltos empleados Table 1. Characterization of asphalts used

\begin{tabular}{|c|c|c|c|c|c|c|}
\hline Propiedades/Properties & Unidades/Units & B-60/70 & B-13/22 & BM-3c & BM-3b & BM-PN \\
\hline Penetración a $25^{\mathrm{a}} \mathrm{C} /$ Penetration at $25^{\mathrm{a}} \mathrm{C}$ & $1 / 10 \mathrm{~mm}$ & 63 & 20 & 56 & 60 & 65 \\
\hline Pto. Reblandecimiento anillo y bola/Softening point ring and ball & ${ }^{\circ} \mathrm{C}$ & 50.6 & 68 & 67.2 & 64.6 & 58.7 \\
\hline Índice de penetración/Penetration index & ---- & -0.5 & 1 & 2.7 & 2.4 & 1.5 \\
\hline Pto. fragilidad Fraass/Fragility point Fraass & ${ }^{\circ} \mathrm{C}$ & -13 & 1 & -17 & ---- & -19 \\
\hline Recuperación elástica/Elastic Recovery & $\%$ & ----- & ---- & 76 & 64 & 42 \\
\hline \multicolumn{7}{|c|}{ Residuo TFOT/Residue TFOT } \\
\hline Variación de masa/Mass variation & $\%$ & -0.14 & 0.5 & -0.24 & ----- & -0.07 \\
\hline Penetración a $25^{\circ} \mathrm{C}$ retenida/Retained penetration at $25^{\circ} \mathrm{C}$ & $\%$ & 65 & 60 & 59 & ---- & 59 \\
\hline Variación del Pto. de reblandecimiento/Variation of Softening point & ${ }^{\circ} \mathrm{C}$ & 6.4 & 7 & 8.4 & ---- & 8.9 \\
\hline
\end{tabular}

En la fase experimental de la investigación, se utilizan 3 tipos de agregados en la elaboración de las probetas a ensayar, uno de tipo granítico para evaluar la tenacidad y una mezcla de agregados de sílice y caliza para evaluar la fatiga.
In the experimental phase of research, 3 types of aggregates are used in the preparation of the test tubes to be used; a granitic type to evaluate toughness, a mixture of silica and limestone aggregates to assess fatigue. 


\section{Metodología}

La fase experimental se realiza en dos etapas. En la primera, se determina la tenacidad de diferentes asfaltos mediante el empleo del ensayo BTD, y en la segunda, se determina la vida a fatiga de una mezcla, fabricada con los mismos asfaltos, mediante el ensayo de flexotracción dinámica.

El procedimiento de ensayo BTD, consiste en someter una probeta cilíndrica, con un entalle en la base a un esfuerzo de tracción paralelo a ésta base y perpendicular al entalle de la probeta.

Las bases de entalladura son colocadas dentro

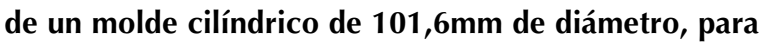
poder ser utilizado en el compactador Marshall, aplicando 50 golpes únicamente en la cara superior.

El ensayo se realiza a una velocidad de desplazamiento constante de $10 \mathrm{~mm} / \mathrm{min}$ y dentro de una cámara climatizada para mantener la temperatura durante la realización del ensayo. La entalladura se abre a medida que provoca la fisuración de la probeta.

Para elaborar la probeta se emplea una mezcla patrón en dos tamaños, según los tamices UNE:

- $80 \%$ del agregado que pasa por el tamiz de $5 \mathrm{~mm}$ y queda retenido en el de $2.5 \mathrm{~mm}$

- $20 \%$ del agregado que pasa por el tamiz $2.5 \mathrm{~mm}$ y queda retenido en el $0.63 \mathrm{~mm}$

- $4.5 \%$ contenido de asfalto

La finalidad de utilizar una mezcla patrón, sin finos ni fíller, es dejar como única variable el tipo y naturaleza del asfalto, por lo que la resistencia dependerá exclusivamente de las propiedades del asfalto utilizado. La temperatura de ensayo fue de $20^{\circ} \mathrm{C}$ (Tabla 2).

De igual manera, para evaluar la fatiga mediante el ensayo de flexotracción a desplazamiento controlado, se han empleado los mismos asfaltos con la finalidad de poder establecer posibles relaciones con la tenacidad.

La mezcla fabricada es una de tipo S-12 (semidensa tamaño máximo $12 \mathrm{~mm}$ ), compuesta por dos tipos de agregados, uno calizo y el otro silíceo con una proporción de asfalto sobre agregado de 4,5\%. El ensayo se ha realizado a la temperatura de $20^{\circ} \mathrm{C}$ y a una frecuencia de $10 \mathrm{~Hz}$. El rango de desplazamiento fijado para los asfaltos convencionales varía desde 160 a $220 \mu \mathrm{m}$; en los asfaltos modificados la amplitud aplicada es mayor, varía de 220 a $360 \mu \mathrm{m}$ (Tabla 3 ).

Como se puede apreciar, se han utilizado dos tipos de granulometrías, ya que con el ensayo BTD se pretende estudiar la tenacidad del asfalto de manera individual, mientras que la otra (tipo S-12) corresponde a un tipo de mezcla asfáltica real, empleada usualmente en la construcción de la carpeta asfáltica.

\section{Methodology}

The experimental phase is conducted in two stages. The first is to determine the toughness of different asphalts using the BTD test, and the second to determine the fatigue life of a mixture, made with the same asphalts through dynamic flexural testing.

BTD test procedure consists of subjecting a cylindrical test tube with a notch at the base to a tensile stress parallel to this base and perpendicular to the notch of the tube.

Recess bases are placed into a cylindrical mold of $101.6 \mathrm{~mm}$ in diameter, to be used with Marshall compactor, applying 50 strokes only at the top side .

The test is performed at a constant displacement rate of $10 \mathrm{~mm} / \mathrm{min}$ and within a chamber heated in order to maintain the same temperature during the trial. The notch is opened as cracking of the test tube is produced.

To prepare the test tube it is used a standard mixture in two sizes, according to the sieves UNE:

- $80 \%$ of agregate passes through a sieve of $5 \mathrm{~mm}$ and is retained by the one of $2.5 \mathrm{~mm}$

- $20 \%$ of agregate passes through the sieve of $2.5 \mathrm{~mm}$ and is retained by the one of $0.63 \mathrm{~mm}$

- $4.5 \%$ asphalt content

The purpose of using a standard mixture, without fines or filler, is to leave as only variable the type and nature of asphalt, so that resistance will depend exclusively on the properties of the asphalt used. Test temperature was $20^{\circ} \mathrm{C}$ (Table 2).

Similarly, to assess fatigue by testing flexural to displacement control, the same asphalt have been used in order to establish possible relationships with toughness.

The mixture produced is of type S-12 (semidense $12 \mathrm{~mm}$ maximum size), composed by two types of aggregates, a limestone one and the other siliceous with a ratio of asphalt aggregate of $4.5 \%$. The test was carried out at a temperature of $20^{\circ} \mathrm{C}$ and with a frequency of 10 $\mathrm{Hz}$. Shift range set for conventional asphalt varies from 160 to $220 \mu \mathrm{m}$; in modified asphalts amplitude applied is higher, ranging from 220 to $360 \mu \mathrm{m}$ (Table 3).

As it can be seen, two types of grain sizes were used, because with BTD test it can be studied the toughness of individual asphalts, while the other (type S-12) corresponds to a real type of asphalt mixture, usually used in asphalt construction. 
Tabla 2. Matriz de ensayos BTD

Table 2. BTD Tests Matrix

\begin{tabular}{||l|c|c|c||}
\hline \multicolumn{3}{|c||}{ ENSAYO BTD/ BTD TEST } \\
\hline $\begin{array}{l}\text { Tipo de Asfalto } \\
\text { Asphalt Type }\end{array}$ & $\begin{array}{c}\text { Probetas a ensayar } \\
\text { Test tubes for trial }\end{array}$ & $\begin{array}{c}\text { Velocidad de aplicación de carga } \\
\text { Speed of load application }\end{array}$ & $\begin{array}{c}\text { Temperatura de ensayo } \\
\text { Test Temperature }\end{array}$ \\
\hline B-60/70 & 3 & & \\
\hline B-13/22 & 3 & $10 \mathrm{~mm} / \mathrm{min}$ & $20^{\circ} \mathrm{C}$ \\
\hline BM-3c & 3 & & \\
\hline BM-3b & 3 & & \\
\hline BM-PN & 3 & & \\
\hline \hline
\end{tabular}

Tabla 3. Matriz de ensayos a fatiga

Table 3. Matrix fatigue tests

\begin{tabular}{||l|c|c|c|c||}
\hline \multicolumn{5}{|c||}{ ENSAYO DE FATIGA A FLEXOTRACCIÓN DINÁMICA/FATIGUE TESTING OF DYNAMIC FLEXURAL } \\
\hline $\begin{array}{l}\text { Granulometría } \\
\text { Grading }\end{array}$ & $\begin{array}{c}\text { Tipo de Asfalto } \\
\text { Asphalt Type }\end{array}$ & $\begin{array}{c}\text { Probetas a ensayar } \\
\text { Test tubes for trial }\end{array}$ & $\begin{array}{c}\text { Amplitud de desplazamiento } \\
\text { Displacement amplitude }\end{array}$ & $\begin{array}{c}\text { Temperatura de ensayo } \\
\text { Trial Temperature }\end{array}$ \\
\hline \multirow{3}{*}{ S-12 } & B-60/70 & 10 & $160-220 \mu \mathrm{m}$ & \multirow{2}{*}{$20^{\circ} \mathrm{C}$} \\
\cline { 2 - 4 } & B-13/22 & 10 & $160-220 \mu \mathrm{m}$ & \\
\cline { 2 - 4 } & BM-3c & 10 & $220-360 \mu \mathrm{m}$ & \multirow{2}{*}{$220-360 \mu \mathrm{m}$} \\
\cline { 2 - 4 } & BM-3b & 10 & $220-360 \mu \mathrm{m}$ & \\
\cline { 2 - 4 } & BM-PN & 10 & \multicolumn{2}{||||}{} \\
\hline \hline
\end{tabular}

\section{Análisis de resultados}

\subsection{Tenacidad}

En los ensayos a tracción directa se registra, para cada asfalto ensayado, el desplazamiento provocado por la variación de la fuerza a tracción. El ensayo se ha realizado a la temperatura de $+20^{\circ} \mathrm{C}$.

En la Figura 1, se aprecia la curva característica de un asfalto sometido a tracción directa. Dicha curva, presenta una pendiente inicial pre-pico que alcanza un valor de fuerza a tracción máxima y desciende con una pendiente post-pico hasta que la fuerza se reduce a cero.

Al analizar la curva característica podemos observar algunos parámetros relevantes como, la fuerza máxima, el módulo secante, el desplazamiento de rotura, la pendiente post-pico y la energía total.

\section{Results Analysis}

\subsection{Toughness}

In the direct tensile test it is recorded for each tested asphalt the displacement caused by variation of tensile strength. Test was carried out at a temperature of $+20^{\circ} \mathrm{C}$.

Figure 1 shows the characteristic curve of asphalt under direct tension. This curve shows an initial pre-peak steep that reaches a maximum tensile strength and falls with a post-peak slope until force is reduced to zero.

Upon analyzing the curve we can observe some relevant parameters such as maximum strength, secant modulus, fracture displacement, the slope post-peak and total energy. 


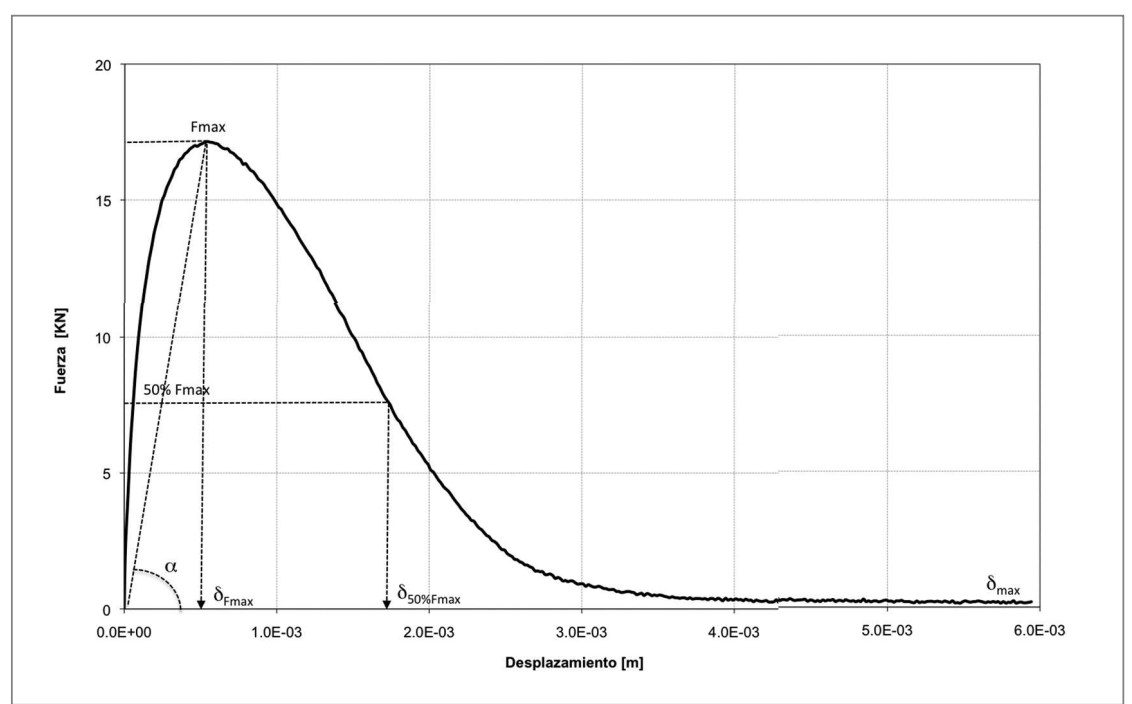

Figura 1. Curva característica de un asfalto sometido a tracción directa Figure 1. Characteristic curve of pavement subjected to direct tension

\section{- Fuerza máxima (Fmáx)}

Se define como la fuerza máxima que es capaz de soportar el asfalto sin sufrir una deformación permanente (rango elástico). La fuerza máxima que es capaz de soportar el asfalto, está relacionada con la temperatura. A bajas temperaturas el asfalto soporta una mayor fuerza de tracción que a temperaturas intermedias o altas.

\section{- Módulo secante $(\alpha)$}

Se obtiene dividiendo la fuerza máxima entre el desplazamiento producido por dicha fuerza máxima. El módulo secante también se conoce como módulo elástico.

\section{- Desplazamiento de rotura $(\delta)$}

En la curva de comportamiento del asfalto podemos distinguir tres tipos de desplazamientos que pueden considerarse de rotura; el primero corresponde al desplazamiento ( $\delta$ Fmáx) que se produce cuando se alcanza el valor máximo de la fuerza a tracción (Fmáx); el segundo, corresponde al desplazamiento $650 \%$ máx) que se alcanza cuando la carga máxima se ha reducido un $(50 \%$ Fmáx) en la curva post-pico y el tercero corresponde al desplazamiento total §máx), cuando la fuerza a tracción se reduce a cero.
- Maximum strength (Smax)

It is defined as the maximum force that can withstand the asphalt without suffering permanent deformation (elastic range). The maximum force that pavement is capable of supporting is related to temperature. At low temperatures the asphalt supports a greater tensile strength than intermediate or high temperatures.

\section{- Secant modulus $(\alpha)$}

It is obtained by dividing the maximum force by the displacement produced by such maximum force. The secant modulus is also known as elastic modulus.

\section{- Fracture displacement $(\delta)$}

At the asphalt performance curve we can distinguish three types of movements that can be considered of braking type; the first one corresponds to the displacement (6Smáx) that occurs when reached the maximum tensile force (Smax); the second one corresponds to displacement $650 \%$ max) reached when the load has been reduced ( $50 \%$ Smax) at the post-peak curve and the third one corresponds to total displacement $\$$ max) when the tensile strength is reduced to zero. 
En la anterior, se representan los tres criterios de fallo descritos anteriormente; el primer criterio (Fmáx$\delta$ Fmáx), no refleja la tenacidad de la mezcla, ya que no considera todo el rango de desplazamiento que el asfalto ofrece. El tercer criterio \&máx), es difícil de determinar ya que, dependiendo del tipo de asfalto analizado, especialmente los asfaltos modificados, la curva puede llegar a ser muy tendida y no llegará a un valor cero de tracción. En cambio, el segundo criterio (50\%Fmáx$\delta 50 \%$ máx), se considera más adecuado para representar la tenacidad, ya que representa el desplazamiento que se produce en la curva post-pico, considerando el rango elástico y plástico del material. Este desplazamiento aumenta cuanto mayor es la temperatura.

\section{- Pendiente post-pico}

Al analizar la pendiente de caída de las curvas, se advierte que a bajas temperaturas, la pendiente es prácticamente vertical ya que la rotura se produce de forma frágil. A temperaturas intermedias, la rotura es más dúctil y la pendiente post-pico se va tendiendo con un desplazamiento de rotura mayor, y a altas temperaturas la pendiente se vuelve casi plana.

\section{- Energía total o tenacidad}

La energía total se obtiene a partir del área bajo la curva fuerza-desplazamiento dividida entre el área de fractura.

A continuación se presentan las curvas fuerzadesplazamiento obtenidas del trabajo experimental del grupo de asfaltos a la temperatura de $+20^{\circ} \mathrm{C}$ (Figura 2).
Here the three failure criteria described above are represented; the first criterion (SmaßSmax) does not reflect toughness of the mix because it does not consider the full range of movement that the asphalt offers. The third criterion (max), is a difficult one to determine because, depending on the analyzed type of asphalt, especially modified asphalts, the curve can become very stretched and will not arrive at zero traction. In contrast, the second criterion ( $50 \%$ Smax $£ 50 \%$ max), is considered more appropriate to represent toughness, because it represents the displacement that occurs in the post-peak curve, considering the elastic range and the plastic of the material. This shift increases the higher the temperature is.

\section{- Slope post-peak}

Analyzing the slope of decline curves, we see that at low temperatures, the slope is almost vertical since the break occurs in a fragile way. At intermediate temperatures, the rupture is more ductile and post-peak slope tends to be of higher rupture displacement, and at high temperatures the slope becomes almost flat.

\section{- Total energy or tenacity}

Total energy is obtained from the area under the force-displacement curve divided by the fracture area.

Below are the force-displacement curves obtained from the experimental work of the group of asphalt at a temperature of $+20{ }^{\circ} \mathrm{C}$ (Figure 2).

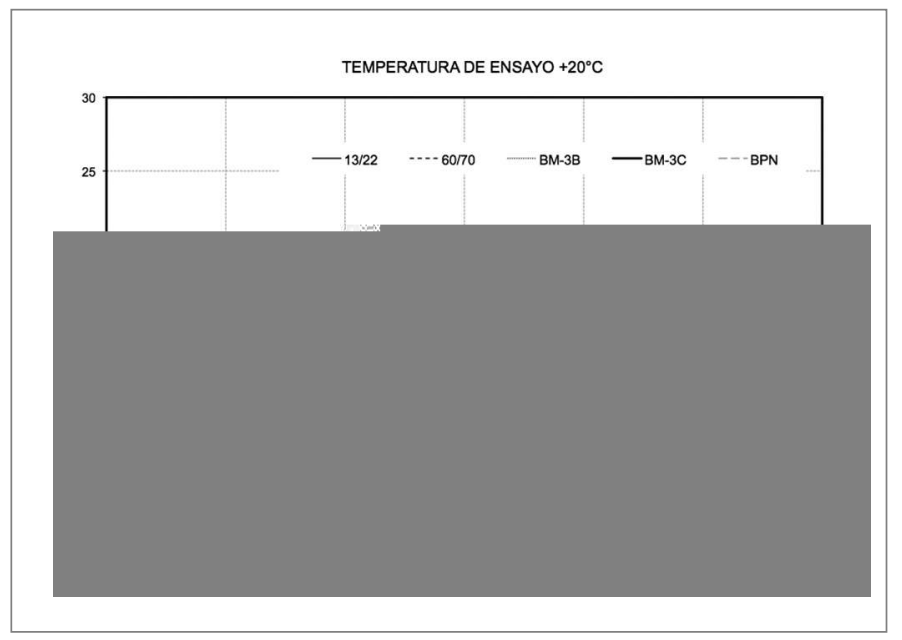

Figura 2. Variación de la tenacidad del grupo de asfaltos a $20^{\circ} \mathrm{C}$ Figure 2. Variation of toughness of the asphalts group at $20^{\circ} \mathrm{C}$ 
Tabla 4. Valores de energía obtenidos Table 4. Energy values obtained

\begin{tabular}{|c|c|c|c|c|}
\hline Asfalto/Asphalt & Fmax/Smax (KN) & Wf (KJ) & Gf (KN/m) & $\sigma$ \\
\hline B-60/70 & 6.90 & 0.00137 & 5.48 & 0.061 \\
\hline B-13/22 & 16.98 & 0.00288 & 11.20 & 0.082 \\
\hline BM-3c & 4.92 & 0.01647 & 6.64 & 0.073 \\
\hline BM-3b & 7.73 & 0.02316 & 9.94 & 0.075 \\
\hline BM-PN & 8.95 & 0.02073 & 8.66 & 0.087 \\
\hline
\end{tabular}

Estos valores son los que se emplean posteriormente para establecer las correlaciones con el comportamiento a fatiga.

\subsection{Fatiga}

A continuación se muestran las leyes de fatiga obtenidas para el grupo de asfaltos mediante el ensayo de flexotracción dinámica (Figura 3).
These are the values that are used later in order to establish correlations with fatigue behavior.

\subsection{Fatigue}

Below are the laws of fatigue obtained for the asphalts group through dynamic flexural test (Figure 3).

Tabla 5. Leyes de fatiga obtenidas de los asfaltos considerados

Table 5. Fatigue laws obtained from the asphalts considered

\begin{tabular}{|c|c|c|c|}
\hline $\begin{array}{c}\text { Tipo de Asfalto } \\
\text { Asphalt Type }\end{array}$ & $\begin{array}{c}\text { Módulo dinámico (MPa) } \\
\text { Dynamic Modulus (MPa) }\end{array}$ & $\begin{array}{c}\text { Ley de fatiga } \\
\text { Fatigue Law }\end{array}$ & $\mathbf{R}^{2}$ \\
\hline B-60/70 & 4.000 & $\varepsilon=0.0018 N^{-0.181}$ & 0.90 \\
\hline B-13/22 & 7.500 & $\varepsilon=0.0015 N^{-0.199}$ & 0.74 \\
\hline BM-3C & 2.100 & $\varepsilon=\mathbf{0 . 0 0 2 2 N}^{-0.134}$ & 0.88 \\
\hline BM-3b & 2.900 & $\varepsilon=0.0023 N^{-0.140}$ & 0.84 \\
\hline BM-PN & 5.900 & $\varepsilon=0.002 N^{-0.190}$ & 0.84 \\
\hline
\end{tabular}




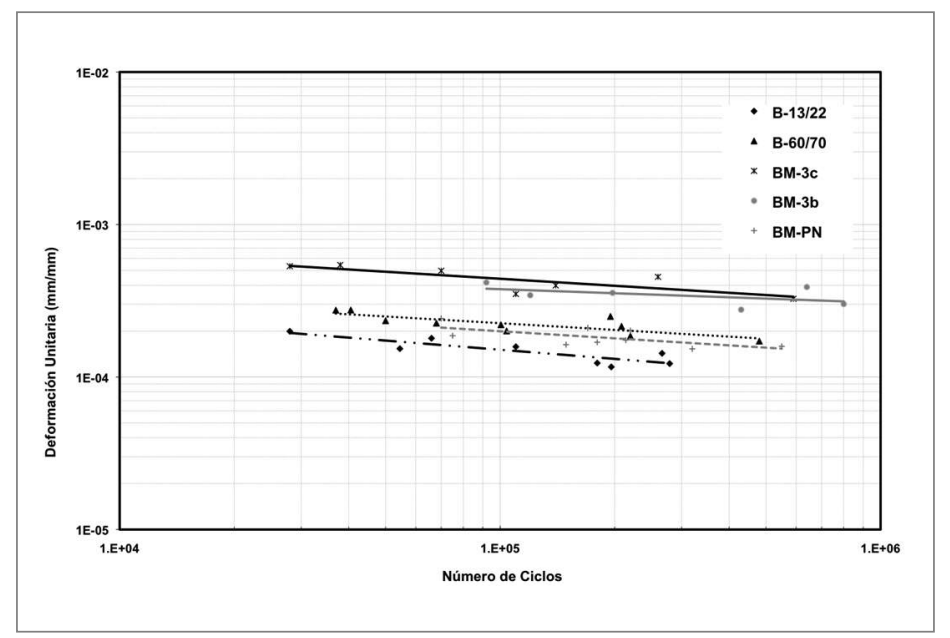

Figura 3. Leyes de fatiga a flexo-tracción dinámica

Figure 3. Fatigue Laws in dynamic flexion traction

Otro procedimiento para evaluar el comportamiento a fatiga de la mezcla, es por medio del ratio de energía disipada a fatiga (Disipated energy ratio, DER), obtenido a partir de la suma acumulada de energía, ciclo a ciclo, hasta el momento de fallo considerado en la probeta.
Another way to evaluate the fatigue behavior of the mixture is through the ratio of energy dissipated upon fatigue (Disipated energy ratio, DER), obtained from the cumulative sum of energy, cycle to cycle, until failure moment considered in the test tube.

$$
D E R=\frac{\sum_{1}^{n} \pi \sigma \varepsilon \operatorname{sen} \phi}{\pi \sigma \varepsilon \operatorname{sen} \phi}
$$

DER = ratio de energía disipada

$\sigma=$ Esfuerzo aplicado

$\varepsilon=$ Deformación aplicada

$\phi=$ ángulo de fase

Al graficar los valores de tensión y deformación de cada ciclo se obtienen los bucles de energía. En los asfaltos convencionales tienen una forma definida, casi elíptica, y a medida que la probeta se va fatigando, los bucles se inclinan y se deforman (Figura 4).

Del mismo modo, se pueden graficar los bucles de energía para los asfaltos modificados (Figura 5), donde se percibe que los bucles se mantienen en un mismo rango de deformación y sobre él, ocurre la distorsión; esto no ocurre en el asfalto convencional donde los bucles se presentan a diferentes niveles de deformación.
DER = ratio of energy dissipated

$\sigma=$ Applied stress

$\varepsilon=$ Applied deformation

$\phi=$ phase angle

By plotting values of stress and strain of each cycle the energy loops are obtained. In conventional asphalts they have a defined form, almost elliptical, and as the test tube fatigues, loops bend and deform (Figure 4).

Similarly, the loops of energy for the modified asphalts can be graphed (Figure 5), perceiving that the loops are kept in the same strain range and above it, distortion occurs; this does not occur in conventional asphalt where loops are present at different levels of deformation. 


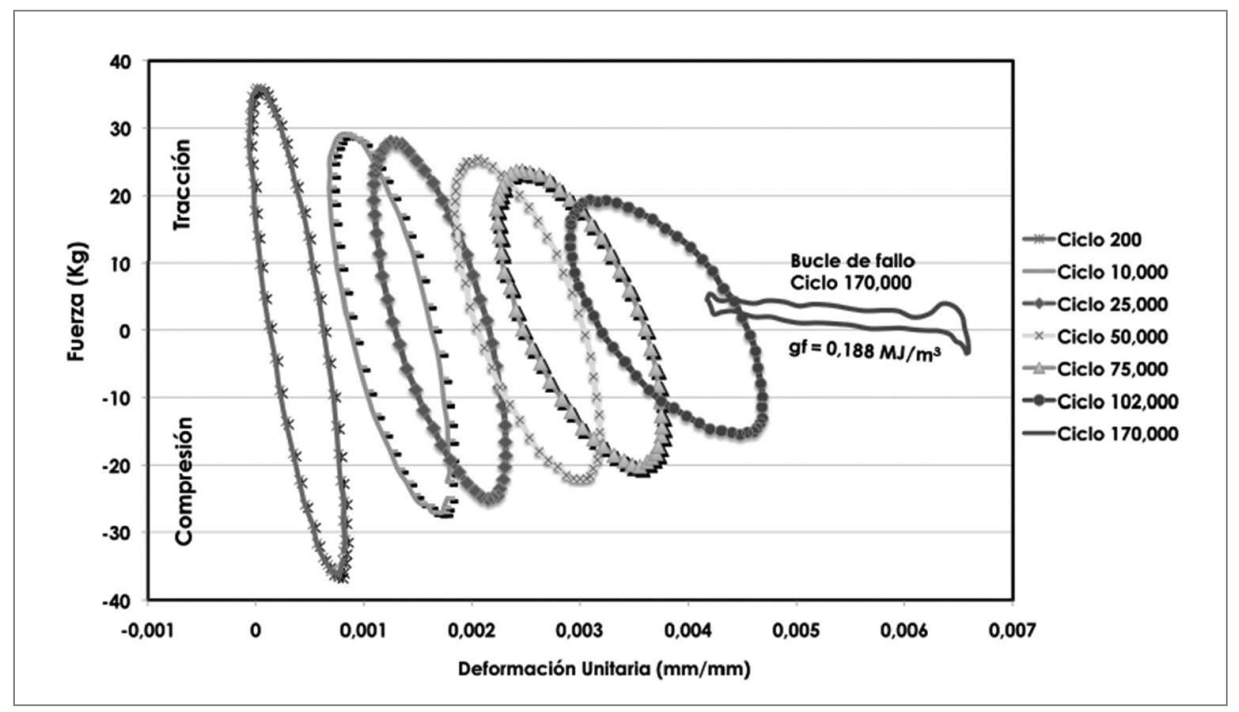

Figura 4. Bucles de energía disipada de un asfalto convencional

Figure 4. Loops of energy dissipated in conventional asphalt

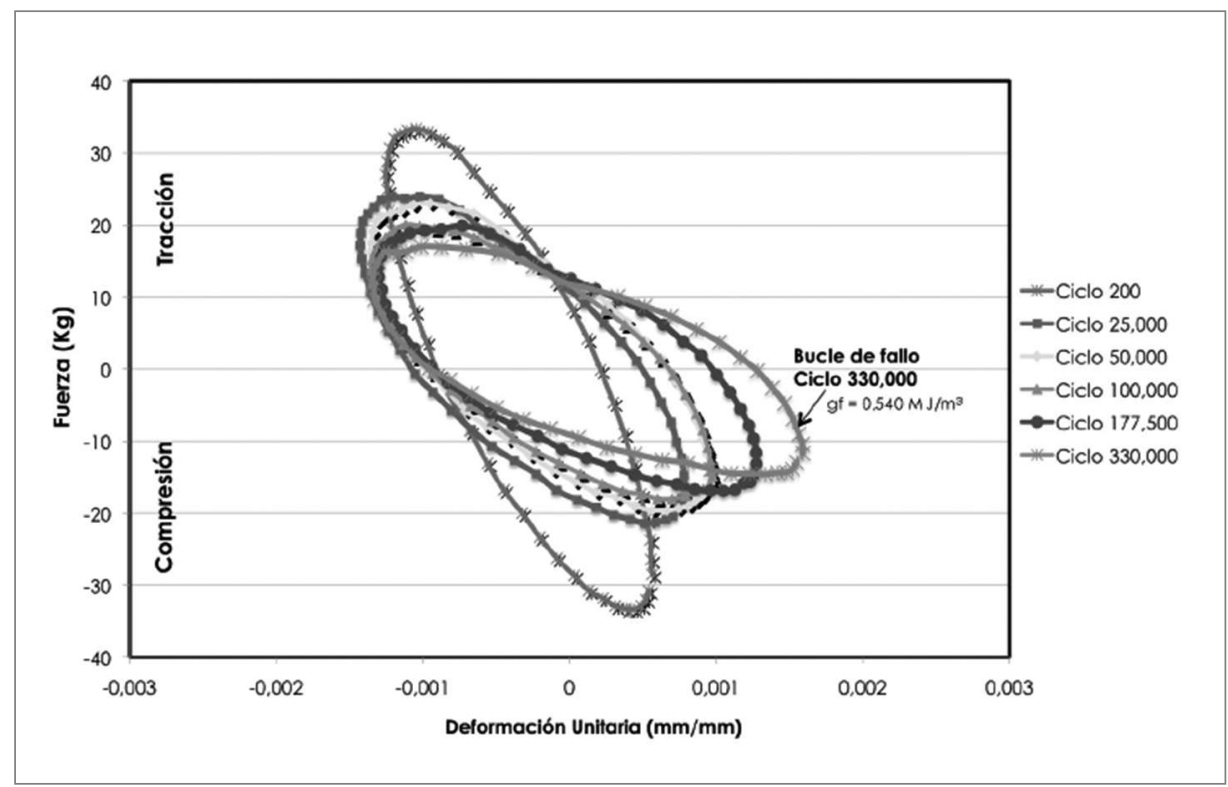

Figura 5. Bucles de energía disipada de un asfalto modificado

Figure 5. Loops of dissipated energy in modified asphalt

A partir de la energía acumulada hasta el ciclo de rotura y el número de ciclos de rotura para cada probeta ensayada, es posible dibujar una ley de energía (Figura 6), parecida a la ley de fatiga presentada anteriormente, que en este caso representa la energía total disipada (DER) frente al numero de ciclos que puede resistir la mezcla.
From the accumulated energy to the breaking cycle and the number of cycles of failure for each test tube assayed, it is possible to draw a power law (Figure 6), similar to the law of fatigue presented above. In this case it represents the total energy dissipated (DER) versus number of cycles that the mix can withstand. 


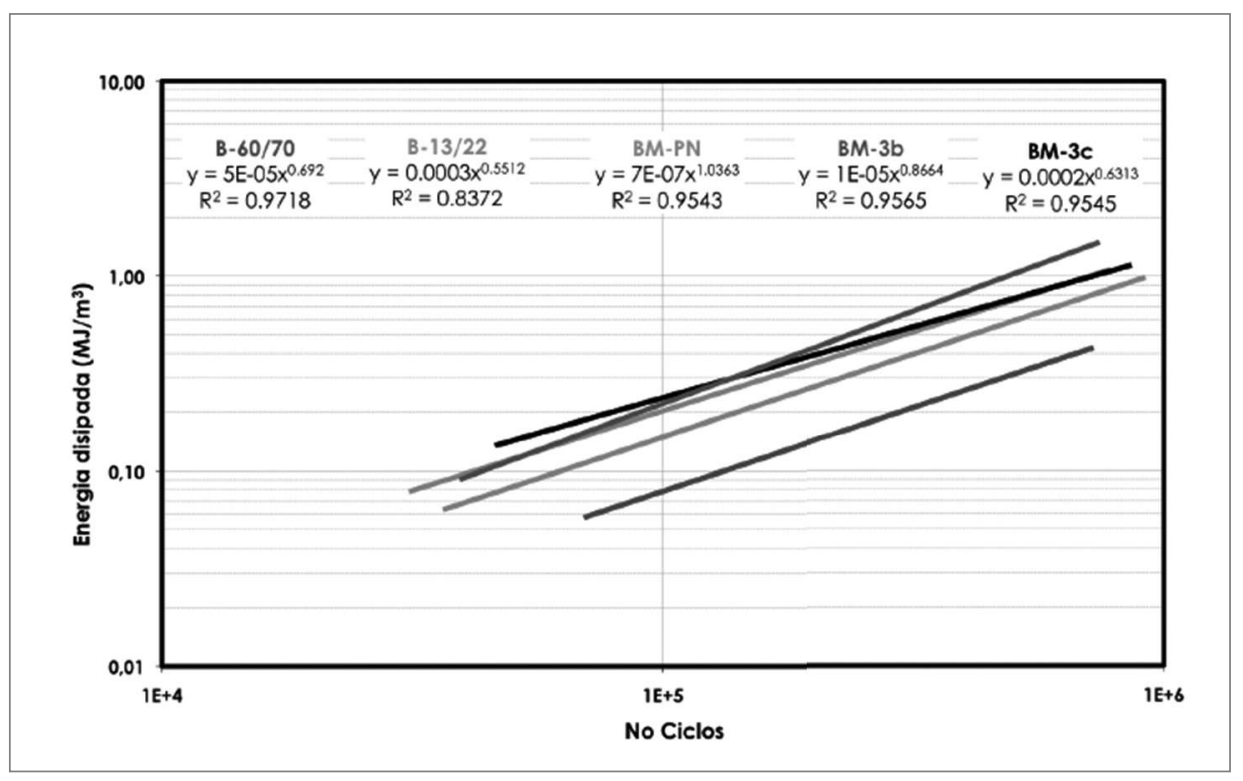

Figura 6. Ley de energía de los asfaltos considerados

Figure 6. Energy Act of asphalts considered

\subsection{Correlaciones entre tenacidad y fatiga}

En base a los ensayos realizados al grupo de asfaltos, se trata, de ver si existe relación entre algunos de los parámetros que definen el comportamiento a tracción directa (ensayo estático) y algunos de los que definen el comportamiento a fatiga (ensayo dinámico). La posible relación entre ambos ensayos permitiría tener una idea de la respuesta a fatiga de una mezcla a partir de los resultados obtenidos en el ensayo a tracción directa, mucho más rápido y sencillo, y poder tener en cuenta esta propiedad en la fase de diseño.

4.3.1 Relación entre desplazamiento de rotura al $50 \%$ de la fuerza máxima a tracción y la deformación en el ciclo 1 obtenida de la ley de fatiga

En primer lugar, se ha estudiado la relación entre el desplazamiento de rotura al $\mathbf{5 0} \%$ de la fuerza máxima a tracción directa y la deformación en el ciclo 1 de fatiga (Figura 7). El desplazamiento de rotura adoptado es el que se produce cuando la carga inicial se ha reducido al $50 \%$ ya que se considera representativo de la tenacidad (pendiente de la curva de caída) y más fácil de determinar que el desplazamiento de rotura total, que para los asfaltos modificados a veces no llega a obtenerse. La deformación a flexotracción en el ciclo 1 de carga se ha obtenido a partir de la ley de fatiga sustituyendo el valor $\mathbf{N}=1$.
4.3 Correlations between toughness and fatigue Based on tests performed at the asphalts group, it deels on seeing whether a relationship exists between some of the parameters that define the behavior to direct tension (static test) and some of the ones that define the fatigue behavior (test). The possible relationship between the two tests would give an idea of the response to fatigue of a mixture based on the results obtained in direct tensile test, much faster and easier, and to take into account this property in the design phase.

4.3.1 Relationship between fracture displacement of $50 \%$ of the maximum tensile strength and strain obtained in cycle 1 of the law of fatigue

First, the relationship between displacement at break at $50 \%$ of maximum force to direct tension and strain in fatigue cycle 1 has been studied (Figure 7). The displacement of fracture adopted is the one that occurs when the initial charge has been reduced to a $50 \%$ and it is considered representative of the toughness (slope of the decay curve) and easier to determine than the displacement of total failure, that sometimes cannot be obtained for modified asphalts. Flexural deformation in loading cycle 1 was obtained from the fatigue law substituting the value $\mathrm{N}=1$. 


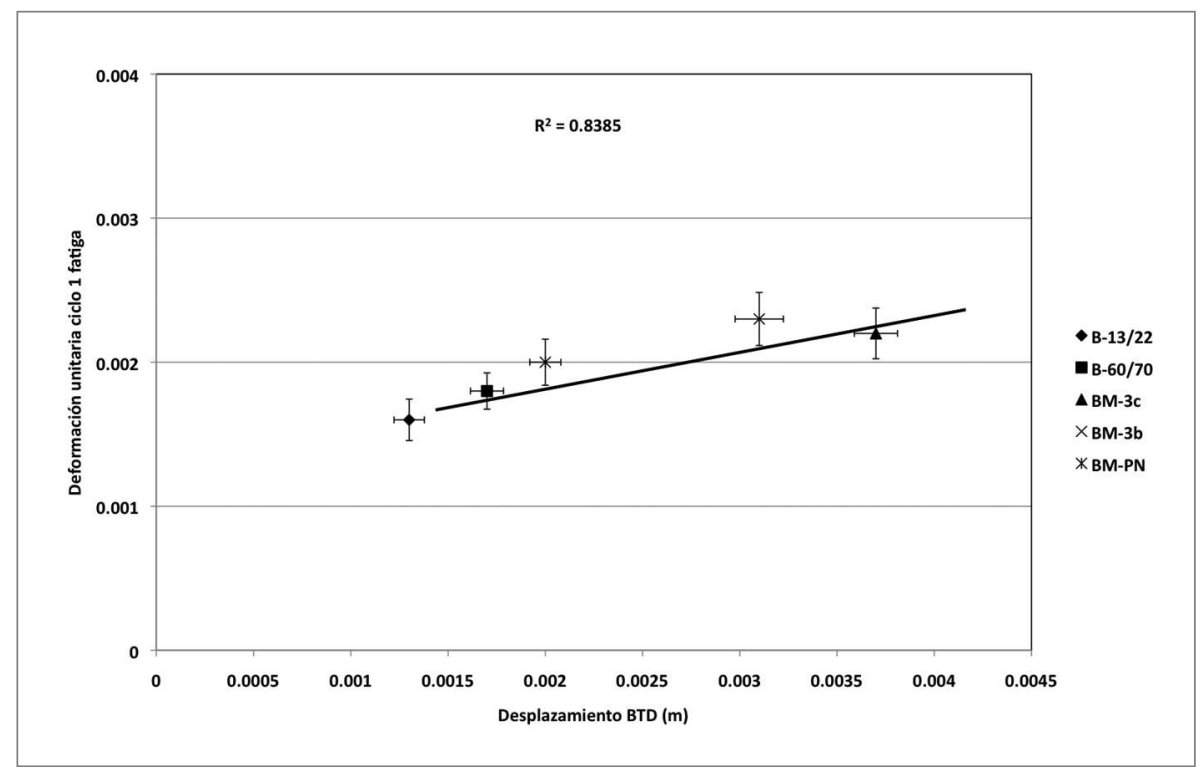

Figura 7. Relación entre desplazamiento de rotura y deformación en el ciclo 1 de fatiga Figure 7. Relationship between displacement at break and strain in the fatigue cycle 1

En la Figura anterior se aprecia que los asfaltos modificados BM-3c y BM-3b tienen un mayor desplazamiento de rotura a tracción directa y también, una mayor deformación a fatiga. El asfalto BM-PN, como en los casos anteriores, se sitúa entre los asfaltos modificados y los de penetración. Después, se sitúan los asfaltos de penetración B-60/70 y B-13/22, respectivamente.

\subsubsection{Relación entre desplazamiento de rotura al $50 \%$} de la carga máxima a tracción y la deformación crítica en fatiga

Además de considerar la deformación a fatiga en el primer ciclo de carga, también se ha considerado la deformación critica de rotura de la mezcla. La deformación critica de rotura corresponde a un valor de deformación a partir del cual la fisura de la probeta se propaga de manera imparable hasta la rotura total, este valor corresponde a la deformación en que la curva de evolución de la deformación presenta un cambio de pendiente brusca (Figura 8).
The above figure shows that BM-modified asphalts $\mathrm{BM}-3 \mathrm{C}$ and $\mathrm{BM}-3 \mathrm{~b}$ have a higher direct tensile fracture displacement and also a greater fatigue deformation. Asphalt BM-PN, as in previous cases, is among the modified asphalt and the penetration ones. Then the asphalt penetration B-13/22 and B-60/70 can be find.

\subsubsection{Relationship between fracture displacement at $50 \%$ of the maximum tension load and fatigue critical strain}

Aside from considering the strain to fatigue in the first charge cycle, it was considered also the critical breaking strain of the mixture. The critical breaking strain corresponds to a strain value from which the crack of the test tube propagates in an unstoppable way until total failure; this value corresponds to the deformation of the evolution curve of deformation and its change into abrupt slope (Figure 8). 


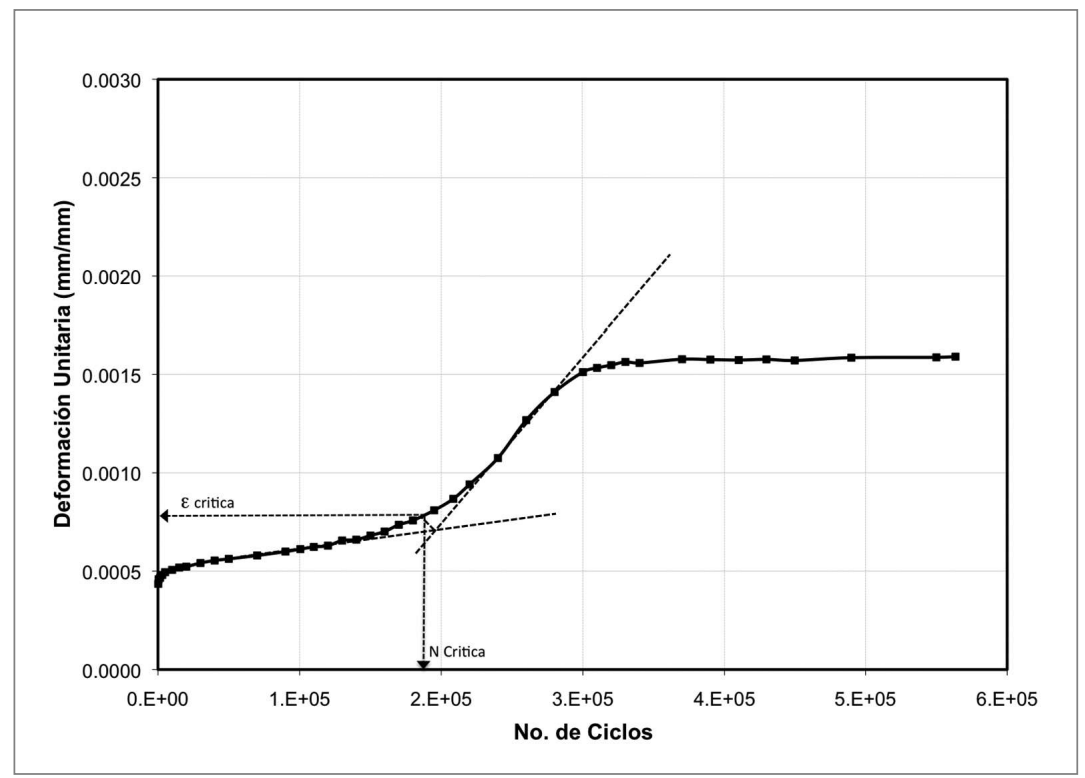

Figura 8. Deformación critica en fatiga

Figure 8. Fatigue critical strain

En la siguiente Figura, se representa la relación entre estos dos parámetros. En ella se aprecia que los asfaltos modificados BM-3c y BM-3b tienen un mayor desplazamiento de rotura a tracción directa y también, una mayor deformación critica a fatiga en la mezcla fabricada con ellos. El asfalto BM-PN, como en los casos anteriores, se sitúa entre los asfaltos modificados y los de penetración. Después, se sitúan los asfaltos de penetración B-60/70 y B-13/22, respectivamente.
The following figure shows the relationship between these two parameters. It shows that the modified asphalts $\mathrm{BM}-3 \mathrm{c}$ and $\mathrm{BM}-3 \mathrm{~b}$ have a higher tensile fracture direct displacement and also a more critical fatigue deformation in the mix made with them. Asphalt BM-PN, as in previous cases, is among the modified asphalt and also among the penetration ones. Then, the asphalt penetration B-60/70 and B-13/22 are placed respectively.

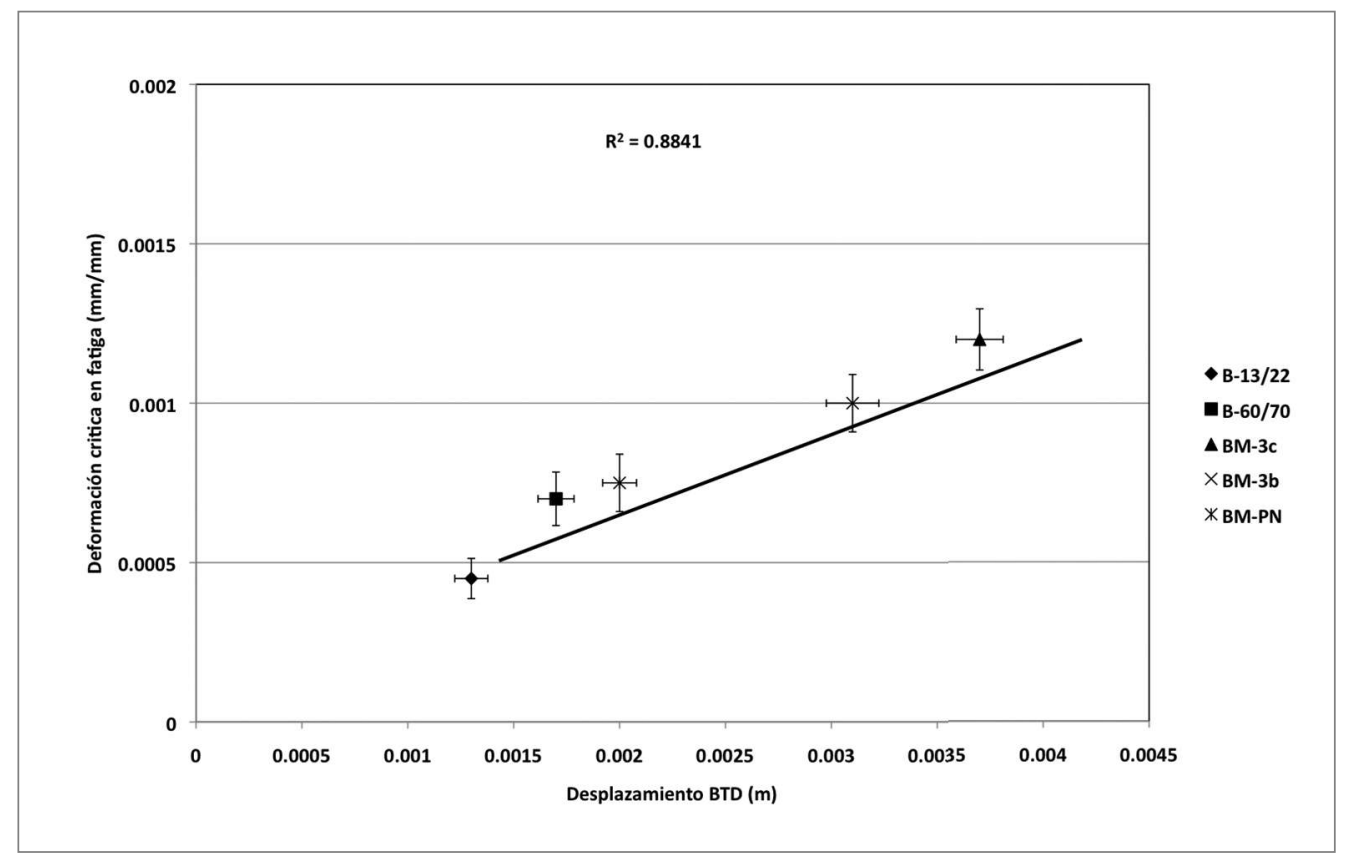

Figura 9. Relación entre desplazamiento de rotura y deformación crítica de fatiga

Figure 9. Relationship between fracture displacement and critical fatigue deformation 
4.3.3 Relación entre desplazamiento de rotura al $50 \%$ de la carga máxima a tracción y la pendiente de la ley de fatiga en el ensayo a flexotracción

Otra de las posibles relaciones entre los dos ensayos (tracción directa y flexotracción), se establece entre el desplazamiento de rotura a tracción directa y la pendiente de la ley de fatiga, para cada unos de los asfaltos, a la temperatura de $20^{\circ} \mathrm{C}$ (Figura 10).
4.3.3 Relationship between fracture displacement at a $50 \%$ of maximum load in tension and the slope of fatigue law upon flexural test

Another possible relation between the two tests (direct tension and flexural) can be established between the displacement at fracture with direct tension and the slope of fatigue law for each of the asphalts, at a temperature of $20^{\circ} \mathrm{C}$ (Figure 10 ).

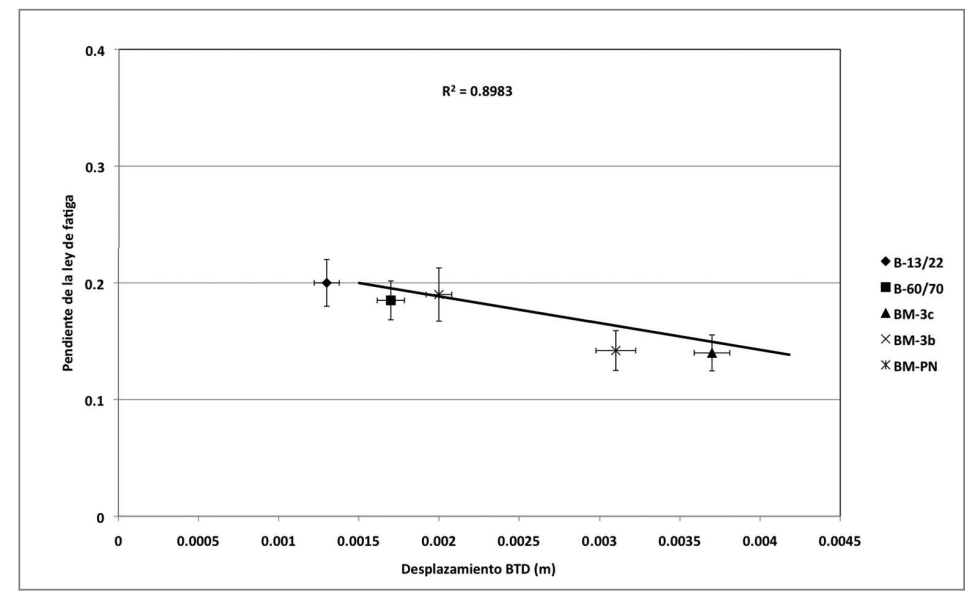

Figura 10. Relación entre el desplazamiento de rotura a tracción y la pendiente de la ley de fatiga

Figure 10. Relation between tensile fracture displacement and the slope of fatigue law

4.3.4 Relación entre módulo secante del asfalto obtenido del ensayo a tracción directa y el módulo dinámico de la mezcla obtenido en el ensayo a flexotracción

Por último, es posible relacionar el módulo secante a tracción directa y el módulo dinámico a flexotracción (Figura 11). En este caso, los asfaltos modificados con menores módulos (secante y dinámico), se sitúan en la parte inferior de la recta de tendencia, seguidos en orden ascendente por el asfalto convencional B-60/70, el asfalto BM-PN y al final el asfalto B-13/22, ya que estos últimos al tener una mayor dureza presentan mayores módulos, tanto a tracción directa como a flexotracción.
4.3.4 Relationship between secant modulus of asphalt obtained from direct tensile test and dynamic modulus of the mixture obtained from flexural test

Finally, it is possible to establish a relationship among the direct tensile secant modulus and flexural dynamic module (Figure 11). In this case, the modified asphalts with fewer modules (drying and dynamic), are at the bottom of the trend line, followed in ascending order by B-60/70 conventional asphalt, asphalt BM-PN and at the end by $B-13 / 22$ asphalt, since the latter ones having higher hardness present larger modules, both of direct and flexural tension.

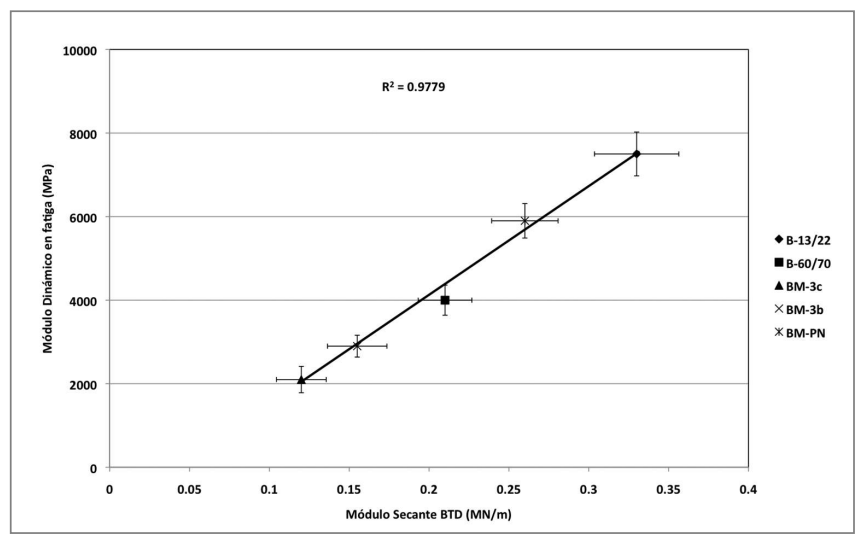

Figura 11. Relación entre el módulo secante a tracción y el módulo dinámico a flexotracción

Figure 11. Relationship between tensile secant modulus and flexural dynamic module 


\section{Conclusiones}

Las correlaciones obtenidas demuestran que la tenacidad del asfalto y la fatiga de la mezcla están, por lo menos, relacionadas, y que por tanto una tiene efecto sobre la otra.

Esta posible relación entre algunos de los parámetros que definen el comportamiento a tracción directa (ensayo estático) y algunos de los que definen el comportamiento a fatiga (ensayo dinámico), permitiría tener una idea de la respuesta a fatiga de una mezcla a partir de los resultados obtenidos en el ensayo a tracción directa, mucho más rápido y sencillo, y poder tener en cuenta esta propiedad en la fase de diseño.

En primer lugar, se han relacionado los valores de desplazamiento al $\mathbf{5 0} \%$ de la carga máxima a tracción directa y la deformación a fatiga en el primer ciclo de carga. En los resultados obtenidos se aprecia que los asfaltos modificados BM-3c y BM-3b tienen un mayor desplazamiento a tracción directa $y$, también, una mayor deformación a fatiga. El asfalto BM-PN, se sitúa entre los asfaltos modificados y los de penetración. Después, se sitúan los asfaltos de penetración B-60/70 y B-13/22, respectivamente.

En segundo lugar, se relacionaron las energías obtenidas a tracción directa y a fatiga; los resultados obtenidos ponen de manifiesto que aunque es difícil establecer una relación cuantitativa entre los valores de energía de los dos ensayos, ambos están relacionados. Una más de las posibles relaciones obtenidas de los dos ensayos, tracción directa y flexotracción, es entre el desplazamiento de rotura a tracción directa y la pendiente de la ley de fatiga para cada uno de los asfaltos. Los asfaltos modificados presentan un mayor desplazamiento a tracción y una menor pendiente en sus leyes de fatiga que los asfaltos convencionales, con una deformación a tracción menor pero con una mayor pendiente de la ley de fatiga.

De manera similar, otra posible relación se establece entre el desplazamiento de rotura a tracción directa y la pendiente de la ley de energía. En este caso, se aprecia que la relación es inversa a la anterior. Los asfaltos convencionales, con un menor desplazamiento de rotura que los asfaltos modificados, tienen una menor pendiente en su ley de energía.

Los módulos secantes a tracción directa y dinámico en flexotracción están también relacionados: cuanto mayor ó menor es uno, mayor o menor es el otro. Los asfaltos modificados con polímeros son los que presentan menores módulos, seguidos por el asfalto convencional B-60/70, el asfalto BM-PN y el asfalto B$13 / 22$, que al tener una mayor dureza, presentan mayores módulos, tanto a tracción directa como a flexotracción.

\section{Conclutions}

Correlations obtained show that asphalt toughness and mix fatigue are related, and therefore one has effect on the other one.

This possible relationship between some of the parameters that define behavior in direct tension (static test) and some that define fatigue behavior (test), would allow to have an idea of the response to fatigue of a mixture from the results obtained in direct tensile test, in a much faster and easier way, and to be in conditions of taking into account this property during the design phase.

First, are the deplacement values related to $50 \%$ of the direct tensile maximum load and strain at fatigue in the first charge. The results obtained shows that modified asphalts BM-3c and BM-3b have a greater shift to direct tension, and also a greater strain to fatigue. Asphalt BM$\mathrm{PN}$ is among the modified asphalts and penetration ones. Then, the penetration asphalts $\mathrm{B}-60 / 70$ and $\mathrm{B}-13 / 22$ are respectively placed.

Second, the energies obtained were related to direct tension and fatigue, the results show that although it is difficult to establish a quantitative relationship between the energy value of the two trials, both are related. One more possible relationship obtained from the two trials, flexural and direct tension, is between the displacement at fracture of direct tension and the slope of the law of fatigue for each of the asphalts. Modified asphalts have an increased traction displacement and a lesser steep in their fatigue laws than the ones of conventional asphalts, with a lower tensile deformation but with a steeper slope of the law of fatigue.

Similarly, another possible relationship is established between the displacement at fracture to direct tension and the slope of the energy act. In this case, the relationship is inverse to the previous one. Conventional asphalts, with a smaller displacement of modified asphalts, have a lower slope on their energy act.

Secant modules to direct tension and dynamic flexural strength are also related: the greater or smaller is one, greater or smaller is the other one. Polymermodified asphalts are those with smaller modules, followed by $\mathrm{B}-60 / 70$ conventional asphalt, asphalt BM-PN and B$13 / 22$ asphalt, that being harder, present greater modules both of direct and flexural tension. 


\section{Referencias / References}

Adhikari Sanjeev, Shen Shihui y You Zhanping (2009), Evaluation of fatigue models of hot-mix asphalt through laboratory testing. In Transportation Research Record: Journal of the Transportation Research Board, No. 2127, TRB, National Research Council, Washington, D.C., 36-42.

Aragao Francisco Thiago, Kim Yong-Rak, Lee Junghun y Allen David H. (2011), Micromechanical model for heterogeneous asphalt concrete mixtures subjected to fracture failure. Jounal of materials in civil enginering, 23, 30.

Centro de Estudios y Experimentación de Obras Públicas (CEDEX) (1990), Ensayo de Fatiga en Flexotracción Dinámica de Mezclas Bituminosas.

D’Angelo John, Kluttz Robert, Dongre Raj, Stephens Keith y Zanzotto Ludo (2007), Revision of the SUPERPAVE high temperature binder specifications: The multiple stress creep recovery test. Journal of the Association of Asphalt Paving Technologists, Vol. 76, 123-162.

Denneman E. (2010), Method to determine full work of fracture from disk shaped compact tension test on hot mix asphalt. Proceedings of the 29th Southem African Transport Conference (SATC 2010), Pretoria, South Africa. ISBN: 978-1-920017-47-7

Fini E. H., Al-Qadi Imad y Masson Jean Francois (2007), A new blister test to measure bond strenght of asphaltic materials. Journal of the Association of Asphalt Paving Technologists, Vol. 76, 275-302.

Kim Hyunwook y Buttlar William G. (2009), Discrete fracture modeling of asphalt concrete. International Journal of Solids and Structures, 46, 2593-2604.

Kowalski Karol J., McDaniel Rebecca S. y Olek Jan (2008), Development of a laboratory procedure to evaluate the influence of aggregate type and mixture proportions on the frictional characteristics of flexible pavements. Journal of the Association of Asphalt Paving Technologists, Vol. 77, 35-70.

Kringos N., Scarpas A. y De Bondt A. (2008), Determination of moisture susceptibility of mastic-stone bond strength and comparación to thermodynamical properties. Journal of the Association of Asphalt Paving Technologists, Vol. 77, 435-478.

Kvasnak A. Andrea y Williams R. Christopher (2007), Evaluation of interaction effects between asphalt binder and fillers using a moisture susceptibility test. Journal of the Association of Asphalt Paving Technologists, Vol. 76, 163-200.

Pérez Jiménez F., Miró Recasens R. y Fonseca Rodríguez C. (1997), Essai BTD pour la Dètermination de la Ténacitè et Resístanse à la Fissuration des Mélanges Bitumineux. Mechanical Test for Bituminous Materials, RILEM, 391-396.

Shen Shihui y Carpenter Samuel. (2007), Development o fan asphalt fatigue model based on energy principles. Journal of the Association of Asphalt Paving Technologists, Vol. 76, 525-574.

Wagoner Michael P., Buttlar William G., Paulino Glaucio H., Blankenship Philip. (2005), Investigation of the fracture resistance of hotmix asphalt concrete using a disk-shaped compact tension test. In Transportation Research Record: Journal of the Transportation Research Board, No. 1929, TRB, National Research Council, Washington, D.C., 183-192. 